\title{
Sedimentary record of subaerial volcanic activity in the basal Ordovician shoal-marine deposits: the Třenice Formation of the Prague Basin, Bohemian Massif, Czech Republic
}

\author{
TOMÁŠ HROCH, MICHAL RAJCHL, PETR KRAFT \& VLADISLAV RAPPRICH
}

\begin{abstract}
The basal Ordovician Třenice Formation represents an initial unit of the preserved infill of the Prague Basin. Volcanic admixture in sediments preserved in the south-western part of the basin suggests subaerial volcanic activity during the deposition of the Třenice Formation. Three principal lithofacies associations were defined within sedimentary record of the Třenice Formation based on petrography and observed sedimentary structures: i) graded conglomerates, ii) lithic sandstones and iii) volcanigenic deposits. The studied sediments were mostly deposited as subtidal sand dunes, locally interbedded with volcaniclastic rocks. They are considered deposits of a marine lower shoreface influenced by ebb-tide currents. Volcaniclastic intercalations are interpreted as deposits of debris flows and turbidity currents that redeposited volcaniclastic material derived from subaerial Křivoklát-Rokycany and Strašice volcanic complexes. - Key words: Prague Basin, shoal-marine sediments, volcaniclastics, Ordovician.
\end{abstract}

HROCH, T., RAJCHL, M., KRAFT, P. \& RAPPRICH, V. 2012. Sedimentary record of subaerial volcanic activity in the basal Ordovician shoal-marine deposits: the Třenice Formation of the Prague Basin, Bohemian Massif, Czech Republic Bulletin of Geosciences 87(2), 359-372 (9 figures). Czech Geological Survey, Prague. ISSN 1214-1119. Manuscript received July 25, 2011; accepted in revised form January 13, 2012; published online March 28, 2012; issued March 30, 2012.

Tomáš Hroch, Charles University in Prague, Faculty of Science, Institute of Geology and Palaeontology, Albertov 6, 12843 Praha 2, Czech Republic, and Czech Geological Survey, Klárov 3, 11821 Praha 1, Czech Republic; tom.hroch@gmail.com - Michal Rajchl, Czech Geological Survey, Klárov 3, 11821 Praha 1, Czech Republic; michal.rajchl@geology.cz・Petr Kraft, Charles University in Prague, Faculty of Science, Institute of Geology and Palaeontology, Albertov 6, 12843 Praha 2, Czech Republic; kraft@natur.cuni.cz • Vladislav Rapprich, Czech Geological Survey, Klárov 3, 11821 Praha 1, Czech Republic; vladislav.rapprich@geology.cz.

The infill of the Prague Basin represents a significant part of the Teplá-Barrandian Unit (shortly referred as the Barrandian area) located in the central part of the Bohemian Massif in the Czech Republic (Fig. 1). The Třenice Formation is the basal lithostratigraphic unit and represents key data set important for reconstruction of the basin evolution. Previous sedimentological research of this unit was, however, focused especially on petrology of the deposits (Kukal 1963) with little information on detailed reconstruction of sedimentary processes. Although the presence of volcanic material within the Třenice Formation is well known (e.g. Kettner 1916a, b; Havlíček \& Šnajdr 1956; Kukal 1963), the relationship between deposition and volcanic activity has not been studied so far. Subaerial volcanism was suspected as a partial source for the sedimentary material of the Trrenice Formation (Kukal 1963) but processes of distribution into the basin were not studied.
The aim of this paper is to present a new sedimentary model of the Třenice Formation including data on sedimentary processes and origin of volcaniclastic material. The research was based on lithofacial and architectural analysis, but limited by small numbers of available sections in the study area.

Our research was focused in the south-western part of the Prague Basin (Fig. 1), where a number of small outcrops allow facies and architectural analysis. Macroscopic description was supported by microscopic studies focused on the origins and sources of volcanic clasts.

\section{Geological setting}

The preserved infill of the Prague Basin represents an erosional relict of the Early Palaeozoic extensional basin (Havlíček 1981). It is about $100 \mathrm{~km}$ long and $25 \mathrm{~km}$ wide 


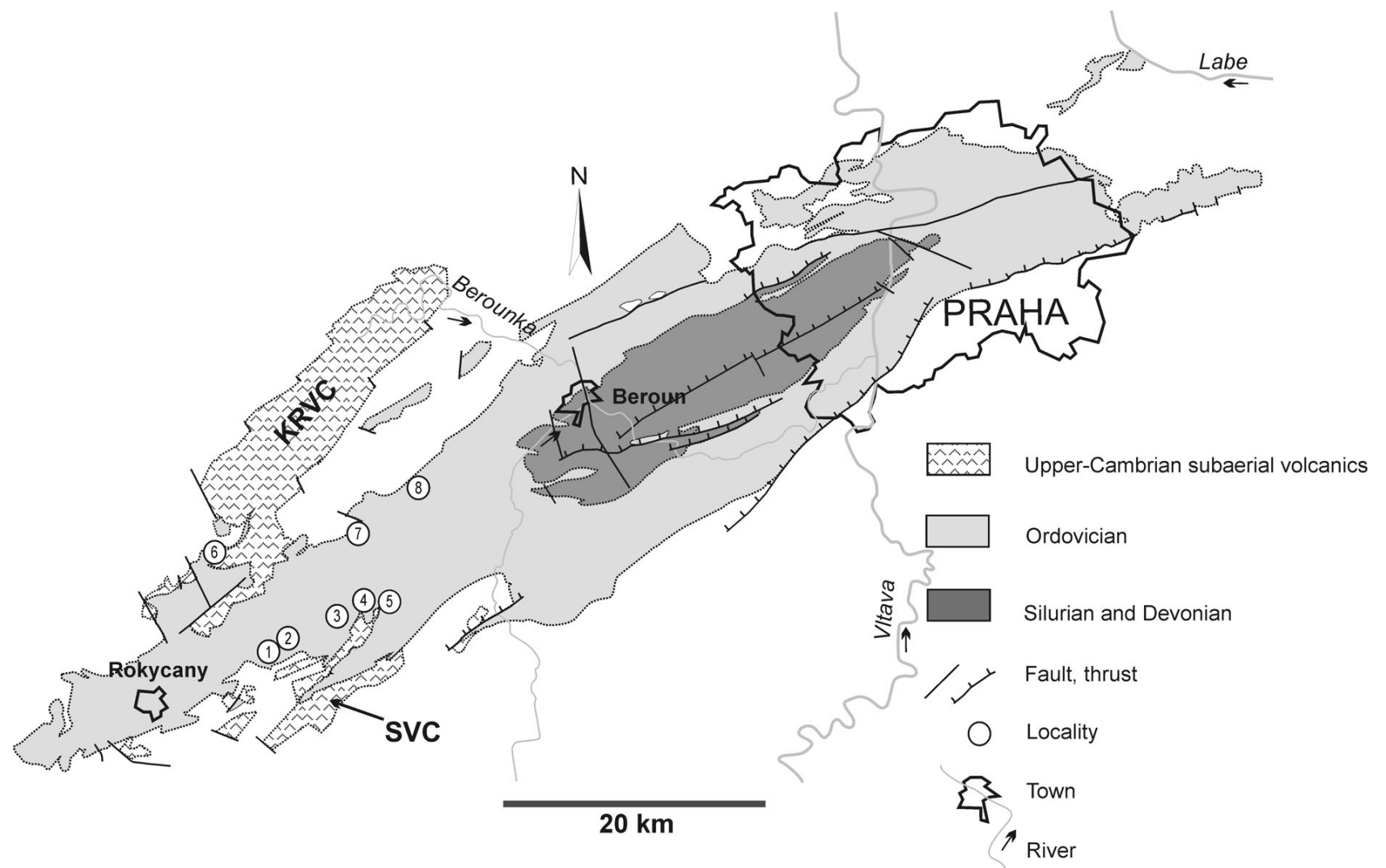

Figure 1. Schematic map of the Prague Basin (modified after Chlupáč et al. 1998, Manda 2008). Documented outcrops and drill-core data are marked: 1 - outcrop Medový Újezd; 2 - drill-core My IX; 3 - drill-core My XI; 4 - Jívina quarry, 5 - outcrop Kleštěnice, 6 - drill-core Rc XI; 7 - Třenice quarry, 8 - outcrop Točník, KRVC - Křivoklát-Rokycany Volcanic Complex, SVC - Strašice Volcanic Complex.

and is elongated in SW-NE direction (Fig. 1). Stratigraphic extent of the preserved deposits ranges from the Lower Ordovician to Middle Devonian. The stratigraphic record is characterised by a predominance of marine siliciclastics that are gradually substituted by carbonates of the Upper Silurian to Middle Devonian age (Havlíček 1981, Kukal 1963). Basin development was accompanied by volcanic activity in some periods, and the intensity of volcanism varied in time. Volcanic activity was concentrated in several centres forming volcanic complexes within the basin. Thus, volcanic and volcaniclastic rocks commonly occur within some parts of the sedimentary succession (e.g. Fiala 1968, 1978; Havlíček 1981). With initial stages of Variscan collision a sedimentation in the Prague Basin terminated, the basin was uplifted and its infill deformed into a complicated synform during the Variscan orogenesis (Havlíček 1981, Melichar 2004).

Kettner (1916b) defined the Třenice Formation as initial deposits of the Prague Basin, which were dated to Tremadocian age based on biostratigraphic data. Sediments of the Trrenice Formation unconformably overlie the Neoproterozoic and Cambrian basement (Fig. 2), their thickness ranges from few metres up to 70 metres (Havlíček \& Šnajdr 1956). Havlíček \& Šnajdr (1956) and Havlíček (1981) supposed that the Prague Basin had the character of a narrow inlet during the Early Ordovician. This hypothesis is supported by facies distribution. The Třenice Formation is formed by coarse-grained siliciclastic sediments (sandstones and conglomerates) in the south-western part of the basin. A high proportion of volcanic fragments (rhyolite and andesite) is common (e.g. Kettner 1916a, Kukal 1963). Havlíček \& Šnajdr (1956) also reported the occurrence of basaltic tuffs. On the other hand, this formation is dominated by fine grained deposits in the north-eastern part of Prague Basin, where coarse-grained deposits as well as admixtured volcaniclastic deposits are scarce. Shale intercalations have been recorded (e.g. Kukal 1963) in the NE part of basin. Kukal (1963) interpreted this facies distribution as the record of basin shallowing from NE to SW.

The fossil content of the Trrenice Formation is generally poor. There are only a few localities with more abundant fossils while the majority of the available sections lack any fossil record. The species diversity is low. Linguliformean brachiopods are strongly dominant in number of specimens as well as species. In addition, linguliformean brachiopods are the unique fossils at most of the Třenice Formation localities. Therefore, the fossil abundance and diversity is exclusively determined by them. Diversified assemblages 


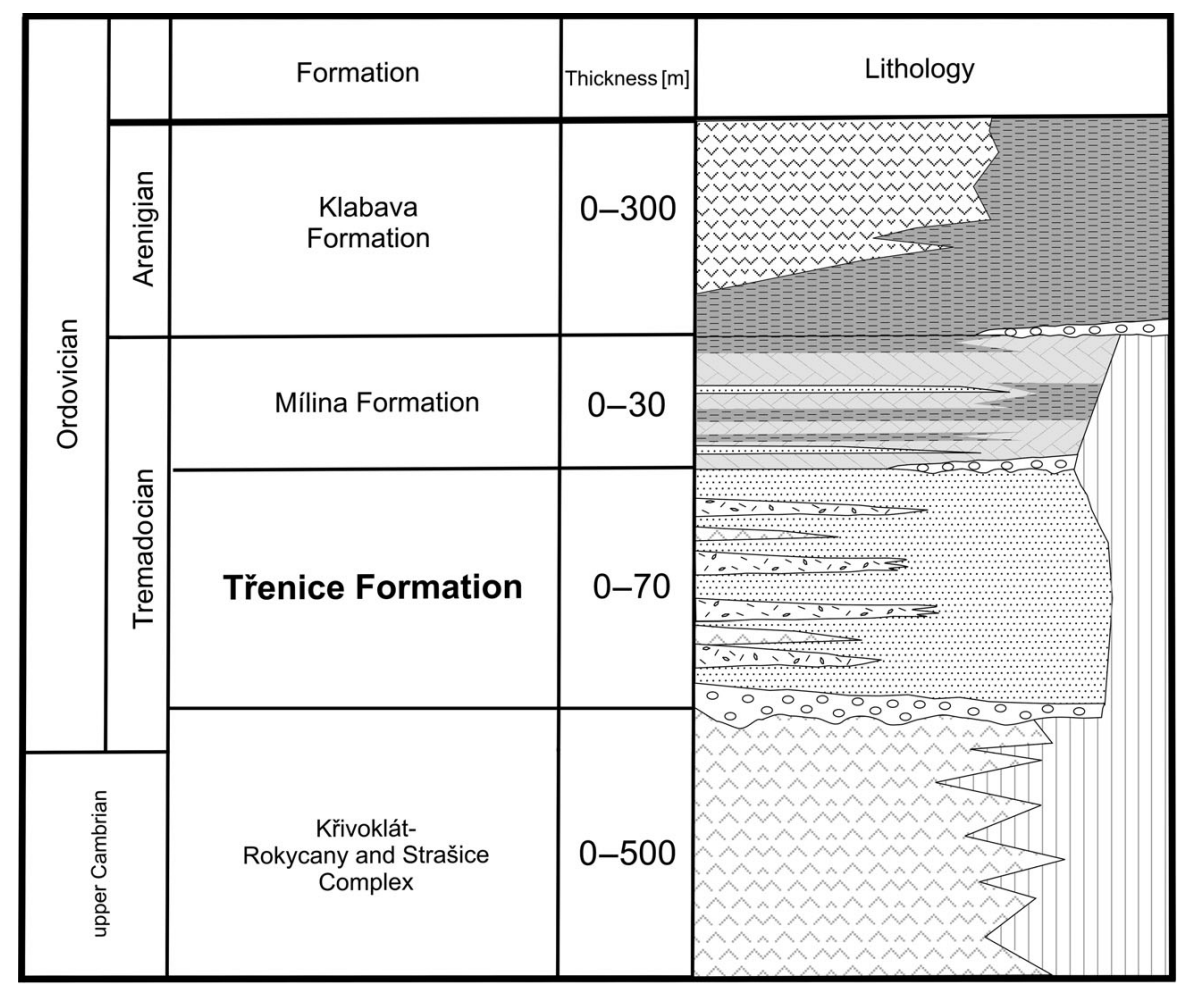

Figure 2. Simplified stratigraphic table of the lower Ordovician part of the Prague Basin fill (modified after Kraft et al. 2001).
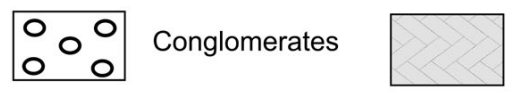

Cherts
Subaerial rhyolites, andesites
Volcaniclastics

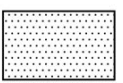

Sandstones

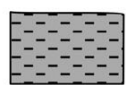

Siltstones, shales

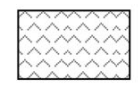

composed of trilobites, echinoderms, linguliformean and rhynchonellyformean brachiopods and others, including one probable bryozoan species, occur only rarely (Mergl 1984). Kraft et al. (unpublished data) distinguished three regions characterized by typical fossil associations. The distribution patterns of these fossil associations do not correspond to the lithological associations in general. It is inferred that patterns result from environmental factors not reflected sedimentary features, but controlled by volcanism (Kraft et al. unpublished data). Duration of deposition of the Třenice formation is estimated at three to four millions years based of occurrence a few index chitinozoans and graptolites (Fatka 1993, Kraft \& Kraft 1999).

\section{Lithofacial analysis}

Three principal lithofacies associations have been recognized forming the Třenice Formation in the south-western part of the Prague Basin: i) graded conglomerates, ii) lithic sandstones, iii) volcanigenic deposits. Definition and characteristics of the associations are based on typical litho- logy, sedimentary structures and geometry of sedimentary bodies. Individual lithofacies were determined based on the Tucker's (2001) classification. All arenitic lithotypes, formerly classified as greywackes (e.g. Kettner 1916a, Havlíček 1981), have been therefore classified as sandstones.

\section{Graded conglomerates}

Description. - This facies association is characterised by two types of clast-supported conglomerates: i) polymictic conglomerates, ii) quartz conglomerates. The clastic material of the polymictic conglomerates is represented by clasts of volcanic rocks - rhyolites and andesites, neoproterozoic cherts, monocrystalline quartz and polycrystalline quartz grains (Fig. 5A). The quartz conglomerates contain clasts of monocrystalline and polycrystalline quartz and clasts of neoproterozoic cherts. Generally, pebbles of both types are subrounded to well-rounded. Conglomerate bodies typically tend to fine upwards; clast size varies from 0.5 to $20 \mathrm{~cm}$. Cobbles occur rarely at the base of some beds. 
Matrix consists of fine-grained conglomerate and it fines upwards into coarse-grained lithic sandstone. Composition of matrix is identical with pebble composition. Fragments of chloritized volcanic glass are common in the matrix (Fig. 5A). Conglomerates are locally cemented by hematite or interbedded with massive or laminated hematite intercalations (Mergl 1984, 2009). Mergl (2002) also observed fragments of brachiopods in conglomerate matrix.

Commonly the sediments of this association formed a basal lag of the Třenice Formation. Polymictic conglomerates generally overlie Cambrian sediments (Fig. 3A) and volcanic rocks of the Krrivoklát-Rokycany and Strašice complexes. Quartz conglomerates are distributed in the areas with Neoproterozoic basement rocks with high content of cherts.

Interpretation. - Conglomerates representing initial deposits of the formation are interpreted as a transgressive lag (sensu e.g. Swift 1968, Walker 1992) formed during sea ingression to the Prague Basin (e.g. Kettner 1916b, Havlíček 1981). A marine origin of the conglomerates is indicated by paleontological data (Mergl 1984). The coarse-grained nature of deposits indicates high energy that could be generated by wave action in a shoreline environment (sensu Curray 1964, Yang 2007). This marine shoreline setting is also supported by stratigraphic position of the conglomerates that unconformably overlie Neoproterozoic (Cadomian) basement or Cambrian volcanics and sediments (see Fig. 2).

\section{Lithic sandstones}

Description. - This facies association is represented by two lithofacies: i) cross-bedded sandstones and ii) massive sandstones. Cross-bedded sandstones (Fig. 4) are represented by fine to coarse-grained sand material. The main components of the sandstones are subangular fragments of basement rocks (mainly Cambrian volcanics, Neoproterozic sediments) monocrystalline quartz, rare polycrystalline grains (Fig. 5B). Opaque Fe-minerals as limonite and hematite are common. Locally, high abundant fragments of chloritized volcanic glass were observed.

Sandstones are cemented by micro-quartz, iron oxides and hydroxides or by carbonates.

Trough cross-bedding of different scale is developed within these deposits. Thickness of individual sets of cross-beds ranges from 20 to $100 \mathrm{~cm}$, with documented lateral extent up to $250 \mathrm{~cm}$. Individual cross-bedded sets are grouped into sedimentary bodies up to $150 \mathrm{~cm}$ thick; their lateral extents locally exceed outcrop size. The individual beds are separated by marked flat erosional surfaces or by layers of volcanogenic sediments, described below.
Massive sandstones are fine-grained to mediumgrained lithic sandstone beds that mostly lack any sedimentary structures. This sandstone forms beds with thickness from several tens of centimetres up to $1 \mathrm{~m}$. They commonly have erosional bases. Locally isolated pebbles of volcanic rocks occur above the base (Fig. 3B), where the massive sandstone overlies volcanic conglomerate. Poorly preserved stratification resembling hummocky-cross stratification is present locally in this facies. Sediments of this association in a few places contain poorly diversified benthic assemblages with dominant linguliformean brachiopods assigned by Havlíček (1982b) to the Hyperbolus feistmanteli Community.

In the north-eastern part of the study area, the sandstone strata are affected by secondary silicification (e.g. in vinicity of Točník; Fig. 1) that obscures original sedimentary structures.

Interpretation. - A marine origin of the deposits is documented by paleontological data. The benthic assemblage with dominant linguliformean brachiopods indicates shallow marine environment (Havlíček 1982a).

Trough cross-bedding within sandstones suggests that the material was transported and deposited in the form of subaquatic dunes with significantly sinuous crests (e.g. Allen 1982, Harms et al. 1982). Due to limited scale of outcrops it is difficult to reconstruct sedimentary bodies of larger scale. Origin of currents that produced the dunes is discussed below. Massive sandstones are interpreted as tempestites, produced by storm remoulding of cross-bedded sandstones or other deposits. The absence of characteristic sedimentary structures (hummocky cross-stratification, swaley cross stratification) could be explained by high energy during deposition and by coarser grain size of sediment in comparison with typical hummocky cross-stratified tempestites (confront e.g. Dumas \& Arnott 2006). Absence of other wave formed sedimentary structures (e.g. wave ripples) indicates depositional conditions under fair water wave base corresponding to lower shoreface environment.

\section{Volcanigenic deposits}

Description. - Two lithofacies represent this facies association: i) volcanigenic conglomerates, and ii) volcanigenic sandstones. Volcanigenic conglomerates (Fig. 3D) are matrix supported poorly sorted sediments, characterized by subangular to subrounded pebbles of 0.5 to $5 \mathrm{~cm}$ in diameter. Slightly altered rhyolites are the most abundant clasts. The rhyolite is slightly vesicular and contains rare quartz phenocrysts $0.2 \mathrm{~mm}$ in diameter (Fig. 5F). Irregularshaped vesicles are partly filled with secondary minerals. Spherulites set on rims of vesicles were also observed documenting originally vitric texture of the rhyolite. Clasts 

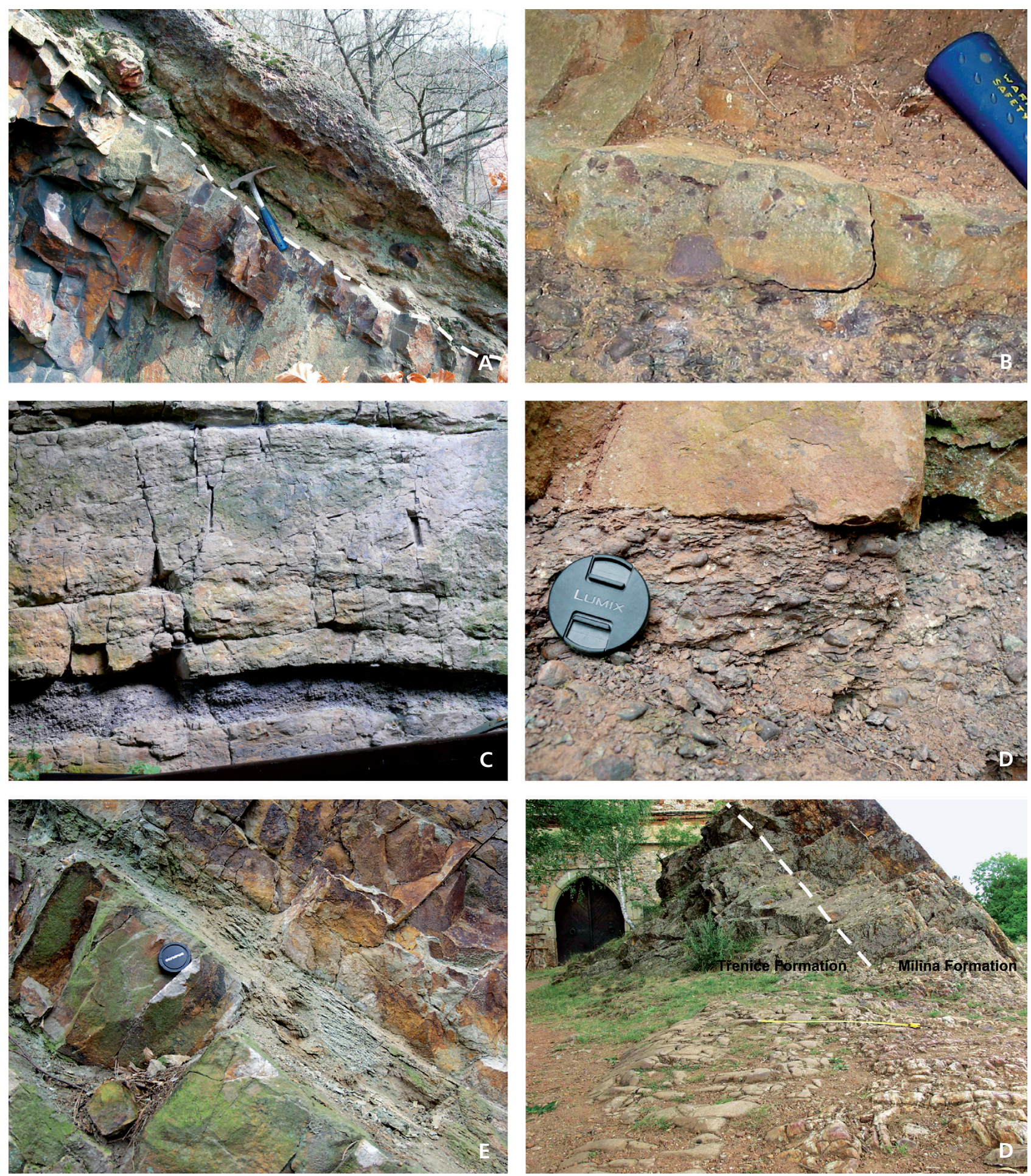

Figure 3. Main lithofacies association of the Třenice Formation. • A - basal polymictic conglomerate of the Třenice Formation overlying Cambrian nonmarine? sandstones. Cobbles are present in the lowermost part of conglomeratic layer. The erosional base is indicated. Medový Újezd quarry. - B - conglomeratic sandstone at the base of massive sandstone bed. Pebbles are redeposited from underlying volcaniclastic conglomerates. Kleštěnice quarry. $\bullet \mathrm{C}$ - intercalacion of the volcaniclastic conglomerate within sandstones shoreface deposits. Kleštěnice quarry. $\bullet \mathrm{D}-$ detail of volcaniclastic matrix-supported conglomerate with subrounded volcanic pebbles. Kleštěnice quarry. $\bullet$ E - intercalation of coarse-grained volcaniclastic sandstones within lithic fine-grained sandtones. Horizontal lamination within volcaniclastic sediments is evident. Týček near Zbiroh quarry. $\bullet \mathrm{F}-$ lithic sandstones of Třenice formation are overlied by cherts of Mílina Formation. Outcrop Točník. 

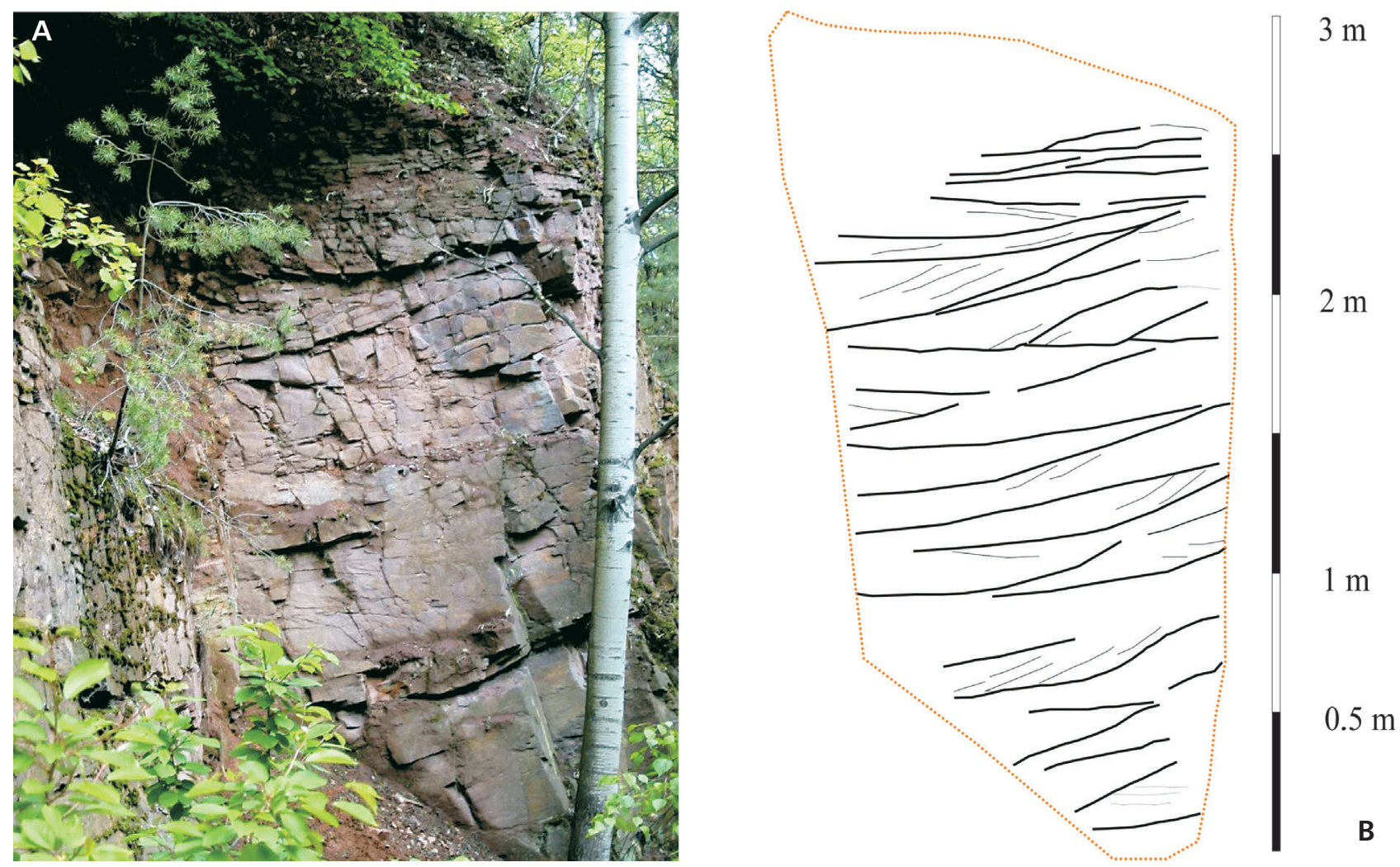

Figure 4. Trough-cross bedding within middle to coarse-grained lithic sandstones (without grain-size changes). Geometry of the sedimentary structures is indicated on the right. Jívina quarries.

of high-grade (eutaxitic) rhyolitic ignimbrites may also occur, but they are very rare (Fig. 5C, D). The fiamme in these eutaxitic ignimbrites are intensively flattened and stretched. Although the size of ignimbrite fragments does not exceed $2.5 \mathrm{~mm}$, small fragments of older rhyolitic ignimbrite can be recognized inside. Matrix consists of clayey and sandy siltstone, locally with angular fragments of chloritized coherent (non-vesiculated) volcanic glass. The outlines of glass fragments in the matrix are straight or bulging, rather than defined by vesicle walls.

Generally, the conglomerates are massive without sedimentary structures. Rarely, horizontal stratification of centimetre scale occurs in the uppermost part of the accumulations. These stratified intervals commonly fine upwards.

Volcanigenic sandstones (Fig. 3E) are represented by fine- to very coarse-grained sandstone of greenish-grey colour, locally with high content of granules up to $0.5 \mathrm{~cm}$ near the base. They consist of fragments of non-vesiculated chloritized volcanic glass (Fig. 5E) and microcrystalline volcanic rocks (both rhyolite and basalt). Subangular grains of monocrystalline quartz occur rarely. Polycrystalline quartz and clinopyroxene are present as an accessory component. Sandstones of this facies are characterized by horizontal lamination of millimetre to centimetre scale
(Fig. 3E), locally with ripple bedding in the uppermost part of sedimentary bodies.

Sediments of these facies form lenticular beds up to $35 \mathrm{~cm}$ thick and few metres to tens of meters wide, characterized by sharp and erosional base. Although the extent of individual beds mostly exceeds the scale of documented outcrops, it is evident that their thickness and grain size decrease laterally. In the study area, these sedimentary bodies are enclosed within the cross-bedded sandstones (described above, see Fig. 3C, 3E).

Intepretation. - Matrix-supported conglomerates mostly lacking sedimentary structures indicate that the material was deposited from cohesive debris flows. High portion of clayey and silty matrix supporting clasts is typical feature of sedimentary record of cohesive debris flows (e.g. Lowe 1982, Stow 1986, Tucker 2001). Volcanigenic sandstones could be interpreted as deposits of volcaniclastic turbidity currents. The massive coarse-grained (granule-rich) intervals near the base of individual sedimentary bodies are interpreted as the Ta member of the Bouma sequence characterized by upper flow regime during deposition (e.g. Bouma 1962, Lowe 1982). Horizontally laminated intervals and overlying ripple-bedded intervals are interpreted as $\mathrm{Tb}$ and $\mathrm{Tc}$ members, respectively. 

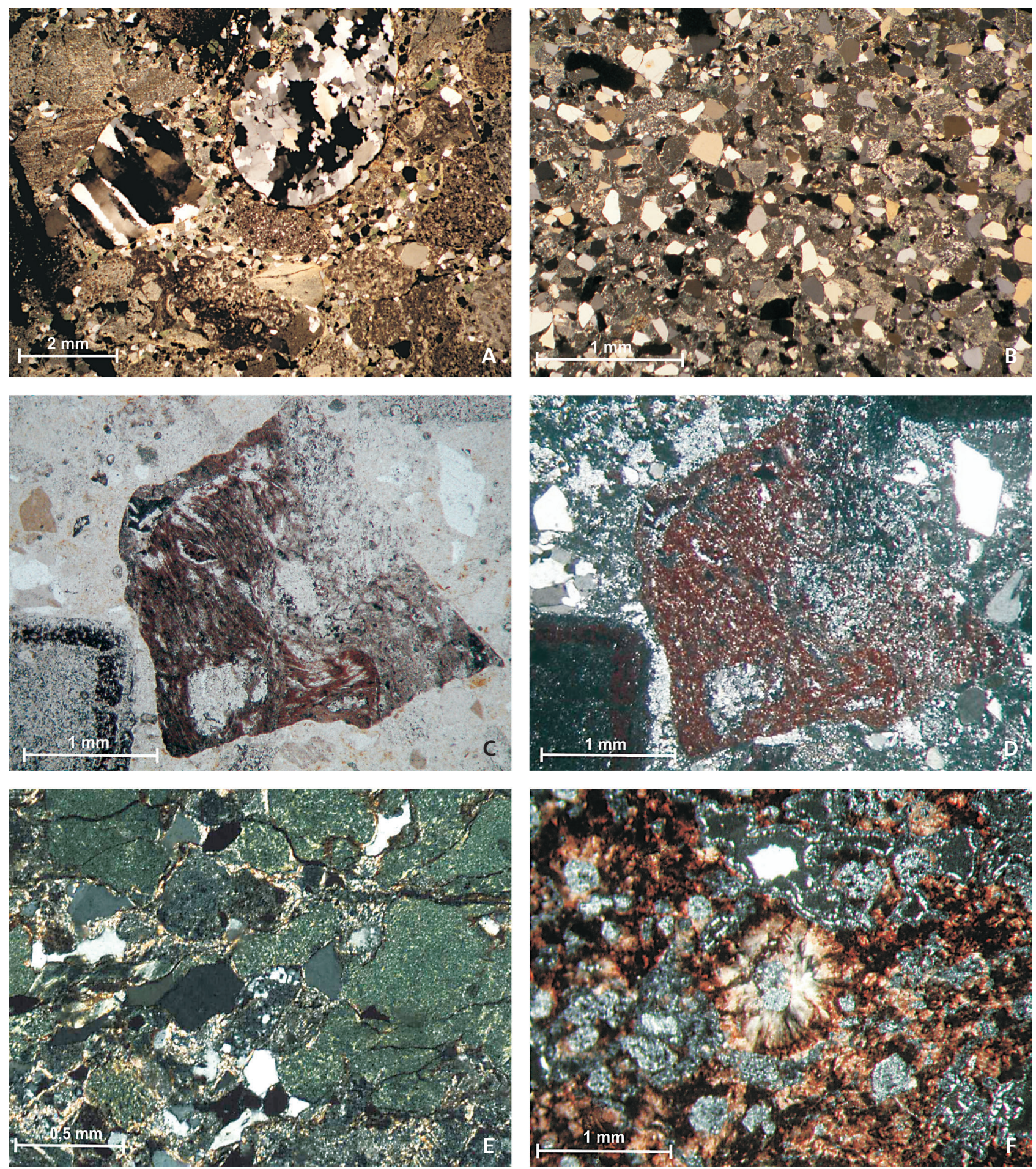

Figure 5. Photomicrographs of principal lithotypes of Třenice Formation. - A - polymictic conglomerates: well-rounded clast of the polycrystalline quartz, subrounded to rounded microcrystaline aphanitic volcanic rocks. The matrix is formed by sandstones with clasts of monocrystalline quartz, lithic fragments (mainly volcanics) and chloritized volcanic glasses. Facies association of the graded conglomerates. Medový Újezd quarry. • B - subrounded grains of monocrystalline quartz, lithic fragments (microcrystaline aphanitic volcanics) and rare volcanic glasses. Association of lithic sandstones. Třenice quarry. $\bullet$ C, D - angular clast of ignimbrite contained fragment of older ignimbrite within. Sample from the conglomeratic base of massive sandstones. PPL (C), CPL (D). Facies association of lithic sandstones. Kleštěnice quarry. - E - subrounded fragments of chloritized volcanic glasses within volcanoclastic sandstones. Facies association of volcanigenic deposits. Kleštěnice quarry. • F - clast with spherulite as a product ofhigh-temperature devitrification. Facies association of volcanigenic deposits. Kleštěnice quarry. 


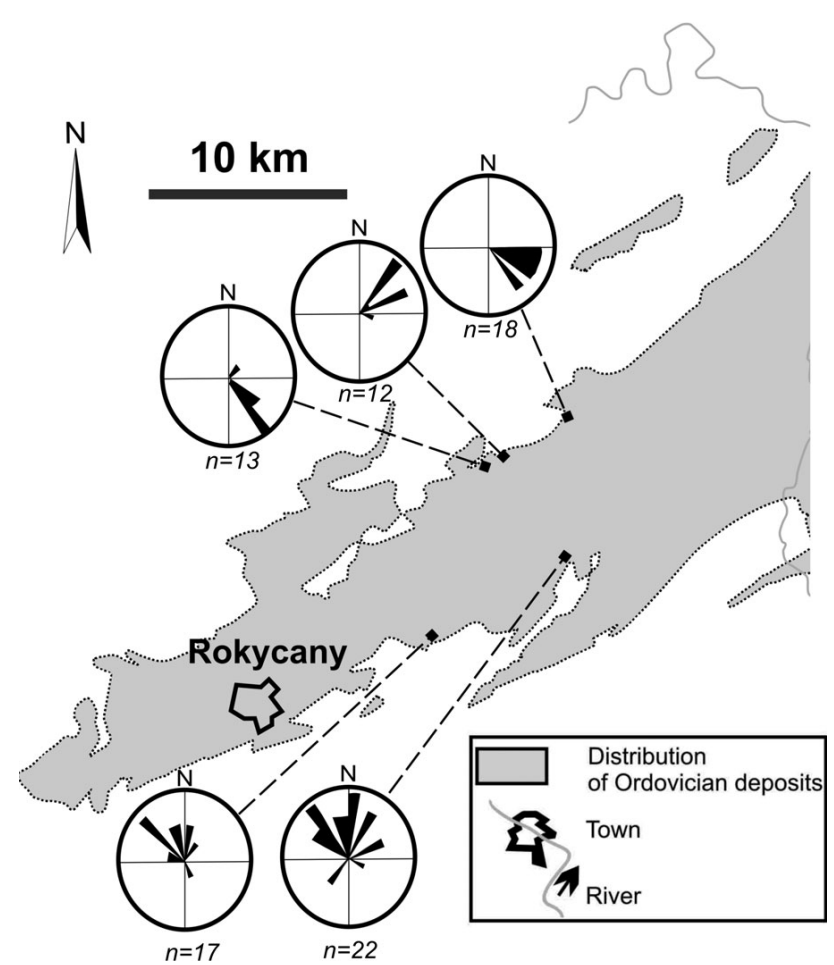

Figure 6. Schematic map of the south-west part of the Prague Basin with diagrams showing results of paleocurrent analysis and number of measurements.

Stratigraphic position of these sediments within the cross-bedded lithic sandstones characterised by presence of marine fauna indicate a shallow-marine depositional environment.

\section{Discussion}

\section{Sedimentary model of the Třenice Formation}

The sedimentary environment of the Třenice Formation was characterised by migration and accumulation of sand dunes that overlie the basal lag of the whole formation across the entire Prague Basin, respectivelly. Generally, sediments of the formation are with a high content of weathering-prone clastic material. This is good evidence of short transport and dominant role of local material, well documented especially by heterogeneity of the basal conglomerate a from side to side. Typical quartz and cherts dominates basal conglomerates in areas with Neoproterozoic sources while those with volcanic rocks are related to sources from upper Cambrian volcanic complexes. Based on the stratigraphic position, the basal lag is interpreted as a transgessive accumulation (transgressive lag) (sensu e.g. Swift 1968, Swift \& Thorne 1991, Trincardi \& Field 1991, Walker 1992, Cataneo \& Steel 2003).

Paleontological content and absence of wave ripples suggest that the sand dunes were deposited in lower shoreface conditions, below fair weather wave base. Marine currents that produced the dunes could be formed in a tidal regime, or by storm impacts (e.g. Raaf \& Boersma 1971, Goldring \& Bridge 1973, Harms 1975, Dalrymple $e t$ al. 1978, McCave \& Langhorne 1982, Leckie \& Walker 1982). However, it is not possible to interpret the precise origin of the current due to limited outcrop extent and absence of some specific sedimentary structures (e.g. reactivation surfaces, tidal bundles, hummocky cross-stratification or swaley cross-stratification). The palaeocurrent analysis shows generally basin-ward migration of the dunes (see Fig. 6). The basin-ward migration of sediment is also indicated by redeposited fragments of linguliformean brachiopods interpreted by Havlíček (1982b) as part of the Benthic Assemblage 1 (sensu Boucot 1975) that lived in an intertidal environment.

The dominance of tidal influence is preferred as more plausible if presumed palaeogeography of the basin during deposition of the Třenice Formation is taken into consideration (sensu Havlíček \& Šnajdr 1956). It is common, tides produce water currents in settings of marine embyments (e.g. Knight 1980, Dalrymple et al. 1990). Finally, storms are not speculated to have forme the currents because to pure occurrence of typical storm sedimentary structures (e.g. Eyles \& Clark 1986, Greenwood \& Sherman 1986, Dumas \& Arnott 2006). However, sporadic storm impacts are preserved by interpreted tempestites within the sedimentary record.

Intercalations of volcaniclastic sediments suggest occasional interruptions of shoreface deposition by debris flows, and turbidity currents originally derived from nearby volcanic centre (see Fig. 9). Volcaniclastic turbidity currents might be transformed from debris flows due to interaction and dilution of the sediment and surrounding water in the subaquatic environment (e.g. Trofimovs et al. 2008). The turbidity currents could be also related with hyperpycnal flows generated by river floods event in the catchement of the basin (e.g. Mulder \& Syvitski 1995, Mulder et al. 2003, Mutti et al. 2003, Plink-Björklund \& Steel 2004).

However, it is evident that the original record of these processes was significantly affected by subsequent reworking due to shoreface sedimentary processes. Only on several subordinate isolated beds of debris flows and turbidity currents deposits is preserved within lower shoreface sandstones.

Sandstones of Třenice Formation are overlain by significantly finer-grained sediments of the Mílina or Klabava formations (siltstones, cherts) (see Figs 3F, 7, 8). Sediments of the both formations probably represent deposition in offshore environments. However, local coarsening of sands in the topmost part of the Třenice Formation (see Fig. 7) is considered to indicate of shallowing due to marine regression and the basal conglomerate locally underlying the Mílina and Klabava formations could be interpreted as a record of subsequent transgression ( $c f$. Havlíček 1981). 


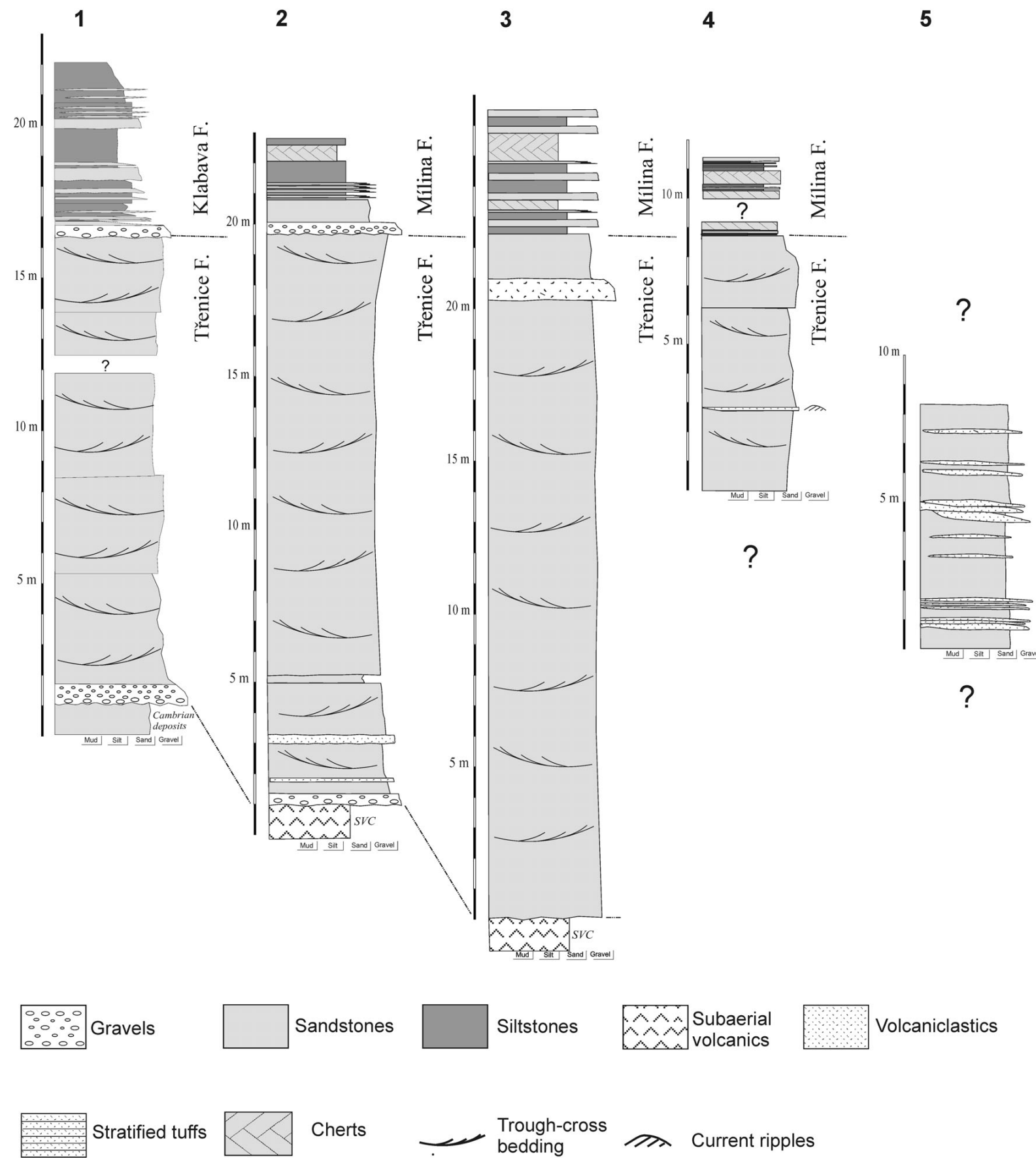

Figure 7. Lithological logs of studied outcrops and selected well data of the Třenice Formation in the south-east flank of basin. Logs of well data were constructed based on descriptions made by Havlíček \& Šnajdr (1957, 1958). 1 - Medový Újezd quarry, 2 - drill core $M y X V, 3$ - drill core $M y$ XVI, 4 - Jívina quarries, 5 - Kleštěnice quarry. Localization of data is shown in Fig. 1.

\section{Origin of volcaniclastic material}

The high proportion of silicic vitric fragments indicates silica-rich volcanism as a significant source of material. An absence of vesicles in volcanic glass fragments and scarce irregular vesicles in rhyolitic fragments argue against fragmentation of volcanic material due to nucleation, growth and disruption of vesicles during eruption (e.g., Fisher \& Schmincke 1984, Sparks 1986, McPhie et al. 1993). Silica rich melts with high viscosity; low ion-diffusion rates and a small temperature difference between solidus and liquidus are prone to form glassy lavas in both subaerial and subaquatic settings (e.g. Fink 1983, McPhie et al. 1993). Poor rounding of the glass fragments argues for short transport 

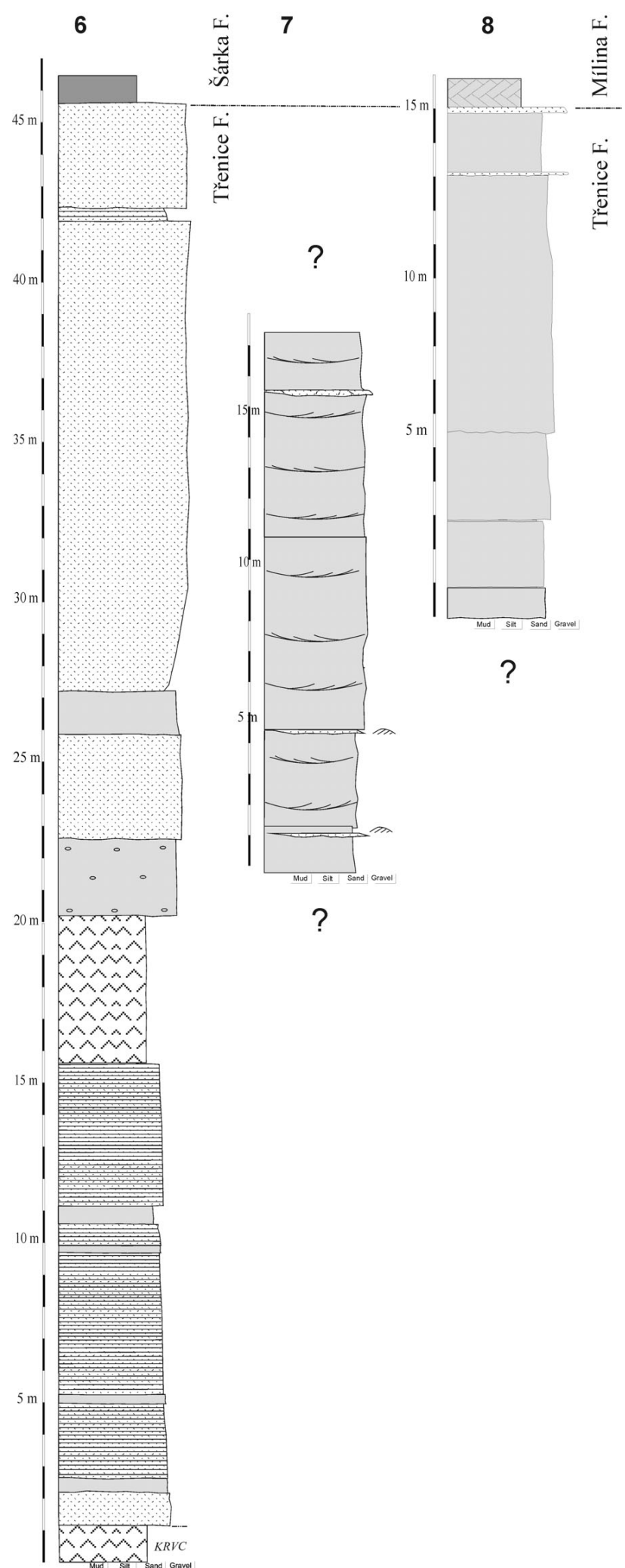

Figure 8. Lithological logs of studied outcrops and selected well data of the Třenice Formation in the north-west flank of basin. Logs of well data were constructed based on descriptions made by Havlíček \& Šnajdr (1957, 1958). 6 - drill core $R \check{c} X I, 7$ - Třenice quarry, 8 - Točník outcrop. Localization of data is shown in Fig. 1. (in scale of X km up to first X0 km). Additionally, any present round shape could be produced by perlitic cracking of the glass during first stages of glass hydration (e.g. Davis \& McPhie 1996). Overall, angular shape dominates among the glass fragments, suggesting autoclastic-, or hydroclastic fragmentation. Origin of such clasts by erosion of ancestral volcanic complex does not seem to be likely. Although, the volcanic glass may persist in unaltered form for millions of years, such conservation can be supposed in coherent obsidian lavas or well welded ignimbrites. Erosion of coherent glassy body would be accompanied by some chemical weathering and we do not suppose, such process could produce angular fragments of fresh glass. Hence, observed angular glass fragments were most likely derived from redeposited autoclastic carapace facies of a viscous lava.

The quartz phenocrysts and vesicles (later partly filled with secondary minerals) served as crystallization nuclei for chalcedonic spherulites. Spherulites represent high-temperature devitrification products of melt under high undercooling conditions (e.g. Lofgren 1971, Dunbar \& McLemore 2001, Castro et al. 2007) common in subaeric conditions (e.g. Stevenson et al. 1994, Smith et al. 2001, Castro et al. 2008), but the same features were described also from subaquatic setting (e.g. Paulick et al. 2004, Sandstå et al. 2011). Even though, formation of spherulites requires undercooling conditions, extremely rapid cooling (quenching) inhibits the formation of spherulites, as the temperature gets quickly below the glass transition temperature (Watkins et al. 2009). For that reason, the occurrence of spherulites in submarine volcanic systems is limited to coherent lava facies and cores of lava pillows (e.g. Paulick et al. 2004, Sandstå et al. 2011). The spherulites could hardly form in rims or even in hyaloclastite breccia of submarine lava. Therefore observed glass fragments are interpreted as clasts derived from autoclastic facies of a subaerial lava.

In summary, the volcanic material most likely comes from a subaerial rhyolitic lava-dome complex in clastsource area. Such observation corresponds to hypothesis of Kukal (1963) suggesting that the Křivoklát-Rokycany Volcanic Complex (KRVC) and Strašice Volcanic Complex (SVC) represented the most probable source of the volcanic material resedimented during accumulation of sediments of Třenice Formation.

Thus, the influx of volcaniclastic material to the shore-face environment had to be provided by exodynamic processes coeval with volcanism in the subaerial setting. It is inferred that subaerial mass flows and alluvial hyperconcentrated currents were the principal processes bringing the volcanic material to the submarine environment in presumbly traversing fan deltas or river deltas (see Fig. 9). 


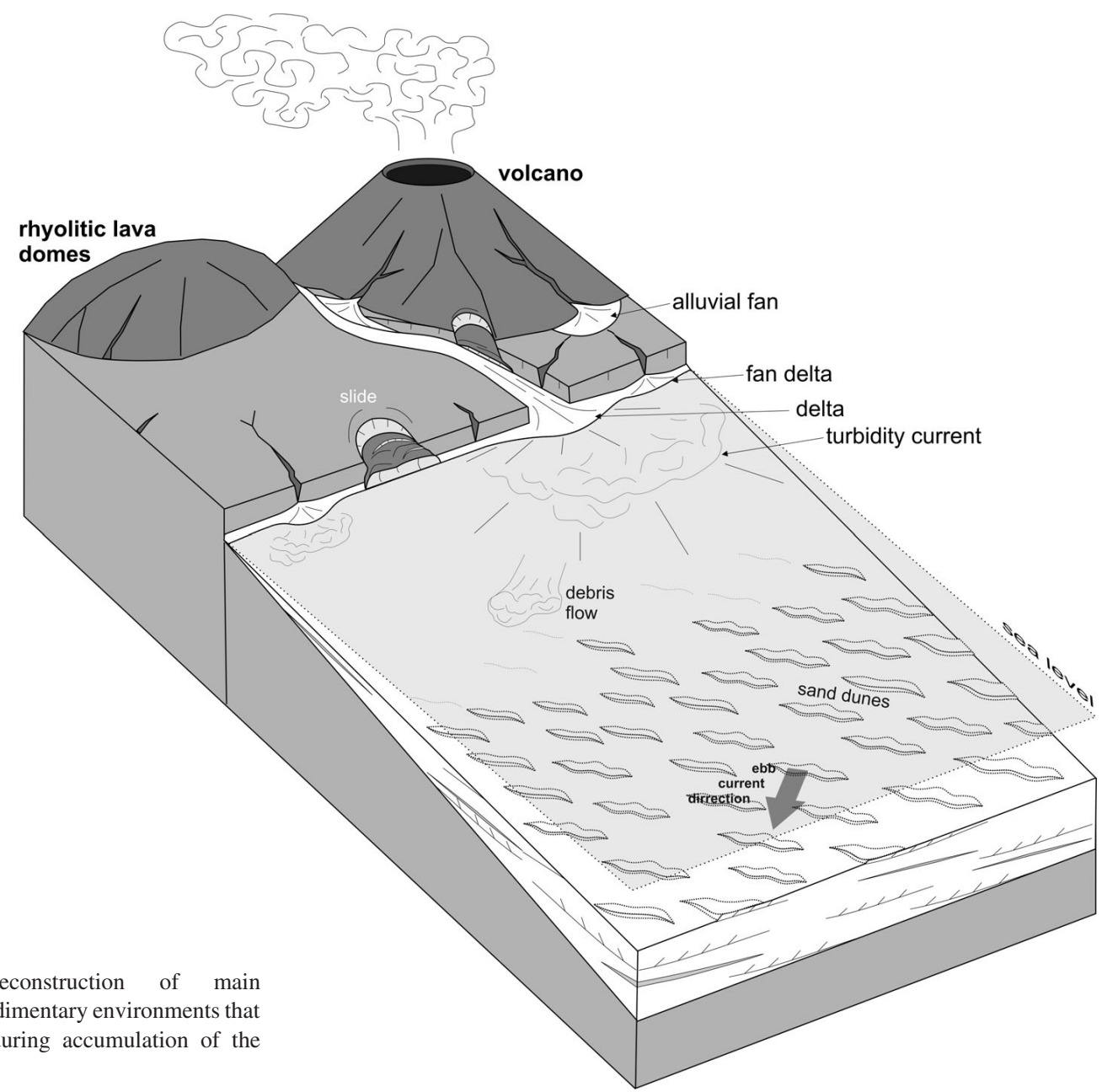
palaeogeographic features and sedimentary environments that were interpreted to be active during accumulation of the Třenice Formation. Out of scale.

\section{Timing of volcanic activity}

The stratigraphic range of the lower Palaeozoic volcanism and relation between the Křivoklát-Rokycany and Strašice complexes and Ordovician marine sediments has not been explicitly resolved. Originally, the Třenice Formation was defined by Kettner (1916a, b) as a coarse-grained siliciclastic succession overlying the volcanic products of the KRVC and SVC. Thus, the volcanic complexes have been considered of late Cambrian age in general.

On the other hand, fragments of argillized glass within the studied volcanic material shows the same geometry as quartz of crystalline rocks, and therefore, these fragments had to be transported in fresh solid stage before argillization, which post dated deposition. Volcanic glasses are generally prone to weathering and argillization (e.g. Hay 1963, Di Figlia et al. 2007, Yokoyama et al. 2008). It have been already discussed the arguments for origin of glass fragments. Coherent bodies of volcanic glass may persist for long time periods. It is supposed, the observed volcanic fragments were derived from autoclastic breccia surrounding some lava body. Preservation of fresh volcanic glass in the form of brecciated material with large reactive surface is highly unlikely. For that reason, it is presumed, erosion and sedimentation of the volcanic material subsequently or shortly after the eruption. Consequently, it suggests persisting activity of the volcanic centres during deposition of the sediments of the Třenice Formation. This interference is supported by observations of some others authors. Havlíček \& Šnajdr (1956) described volcaniclastic deposits of rhyolite composition with fragments of Ordovician linguliformean brachipods from north-western flank of the Prague Basin. Havlíček \& Šnajdr $(1957,1958)$ also reported rhyolitic volcaniclastics within the Třenice Formation and at the basal portion of the overlying Klabava Formation from drill cores in south-eastern flank of the basin. Porphyritic tuffs corresponding to the Strašice Volcanic Complex were also described in a succession of probably Early Ordovician sandstones by them. However, it has not been definitely supported by published radiometric data: 499 Ma by Drost et al. (2004), and $474 \mathrm{Ma}$ by Vidal et al. (1975), later recalculated to ca 494 Ma by Fatka et al. (1998), that proved the volcanic activity into age of Cambrian-Ordovician boundary in general. Based on the above 
mentioned facts, continuation of the late Cambrian subaerial volcanic activity until the Early Ordovician is interpreted in the Prague Basin area (Fig. 1).

\section{Conclusions}

The sedimentary environment of the Třenice Formation is interpreted to have been a marine lower shoreface characterised by sand dunes migrating basinwards due to predominant influence of ebb-tide currents. However, temporal effect of storms is also speculated. Sporadic interruption of the shoreface deposition by volcaniclastic density currents is recorded within the sediments of the Třenice Formation. Petrography of preserved volcanic material suggests that the material was most likely derived from autoclastic breccia associated with subaerial rhyolitic lava-dome complex and subsequently resedimented by combination of subaerial and subaquatic processes to the shoreface environment. The Křivoklát-Rokycany Volcanic Complex (KRVC) and Strašice Volcanic Complex (SVC) located belong the margins of basin are speculated as the most probable source of this volcanic material preserved in the sediments of Třenice Formation. The character of the volcaniclastic products illustrate possible decreasing but still surviving activity in the subaerial volcanic centres during the Early Ordovician in area of the Prague Basin.

\section{Acknowledgment}

The research was financially supported by the Grant Agency of the Czech Republic through the project No. P210/10/2351 (to T. Hroch), 205/09/1521 (to P. Kraft) and through project MSM0021620855 of the Ministry of Education, Youth and Sport of the Czech Republic. The initial sedimentological studies were supported by the Grant Agency of Academy of Sciences of the Czech Republic, project No. IAA3013406. The research has been held within the framework of Research Plans of the Czech Geological Survey (MZP0002579801). We are also grateful to Tomáš Přikryl for help in construction of some figures used in the manuscript and František Vacek for constructive comments on an earlier version of manuscript. The manuscript significantly benefited from constructive comments in rewievs by James D.L. White and an anonymous reviewer as well as from comments of the handling editor.

\section{References}

AlLEN, J.R.L. 1982. Sedimentary structures, their character and physical basis. 1288 pp. Elsevier Science, New York.

Boucot, A. 1975. Evolution and extinction rate controls. 427 pp. Elsevier, Amsterdam.

Bouma, A.H. 1962. Sedimentology of some flysch deposits: A graphic approach to facies interpretation. 168 pp. Elsevier, Amsterdam.
Castro, J.M., Beck, P., Cottrell, E. \& Tuffen, H. 2007. Spherulites record crystallization, degassing, and oxidation-reduction mechanisms in obsidian flows. Eos, Transactions American Geophysical Union 88(52), Fall Meeting Supplement, Abstract V14A-07.

Castro, J.M., Beck, P., Tuffen, H., Nichols, A.R.L., Dingwell, D.B. \& MARTIN, M.C. 2008. Timescales of spherulite crystallization in obsidian inferred from water concentration profiles. American Mineralogist 93, 1816-1822. DOI 10.2138/am.2008.2904

Cattaneo, A. \& SteEl, R. 2003. Transgressive deposits: a review of their variability. Earth Science Reviews 62, 187-228. DOI 10.1016/S0012-8252(02)00134-4

CurRay, J.R. 1964. Transgressions and regressions, 175-203. In Miller, R.L. (ed.) Papers in Marine Geology. Macmillan, New York.

Chlupáč, I., Havlíček, V., KŘíž, J., Kukal, Z. \& Štorch, P. 1998. Palaeozoic of the Barrandian (Cambrian to Devonian). 183 pp. Czech Geological Survey, Prague.

Dalrymple, R.W., Knight, R.J. \& Lambiase, J. 1978. Bed forms and their hydraulic stabilityrelationships in a tidal environment, Bay of Fundy, Canada. Nature 275, 100-104. DOI 10.1038/275100a0

Dalrymple, R.W., Knight, R.J., Zaitlin, B.A. \& Middleton, G.V. 1990. Dynamics and facies model of a macrotidal sandbar complex, Cobequid Bay - Salmon River estuary (Bay of Fundy). Sedimentology 37, 577-612. DOI 10.1111/j.1365-3091.1990.tb00624.x

DAvis, B.K. \& McPhIE, J. 1996. Spherulites, quench fractures and relict perlite in a Late Devonian rhyolite dyke, Queensland, Australia. Journal of Volcanology and Geothermal Research 71, 1-11. DOI 10.1016/0377-0273(95)00063-1

Di Figlia, M.G., Bellanca, A., Neri, R. \& Stefansson, A. 2007. Chemical weathering of volcanic rocks at the island of Pantelleria, Italy: Information from soil profile and soil solution investigations. Chemical Geology 246, 1-18.

DOI 10.1016/j.chemgeo.2007.07.025

Drost, K., Linnemann, U., McNaughton, N., Fatka, O., Kraft, P., Gehmlich, M., Tonk, C. \& Marek, J. 2004. New data on the Neoproterozoic - Cambrian geotectonic setting of the Teplá-Barrandian volcano-sedimentary successions: geochemistry, U-Pb zircon ages, and provenance (Bohemian Massif, Czech Republic). International Journal of Earth Sciences 93, 742-757.

DOI 10.1007/s00531-004-0416-5

Dumas, S. \& ARnotT, R.W.C. 2006. Origin of hummocky and swaley cross-stratification- The controlling influence of unidirectional current strength and aggradation rate. Geology 34, 1073-1076. DOI 10.1130/G22930A.1

DunBar, N.W. \& McLemore, V.T. 2001. The origin of rhyolitic spherulites at Rockhound State Park, New Mexico. New Mexico Geology 23, 22.

Eyles, N. \& Clark, B.M. 1986, Significance of hummocky and swaley cross-stratification in late Pleistocene lacustrine sediments of the Ontariobasin, Canada. Geology 14, 679-682. DOI 10.1130/0091-7613(1986)14<679:SOHASC >2.0.CO;2 
FatKa, O. 1993. Chitinozoans and acritarchs in latest Tremadoc-early Arenig sediments of the Prague Basin, Czech Republic. Special Papers in Palaeontology 48, 29-36.

FatKa, O., FrÝda, J., Kachlík, V., KRaft, P. \& Dolejš, D. 1998. Sedimentary and volcanic events in the Teplá-Barrandian crustal segment (Bohemia) as a response to dated intracrustal processes, 136-137. In Linnemann, U., Heuse, T., Kraft, P., FatKa, O., Brocke, R. \& ERdtmann, B-D. (eds) Pre-Variscan terrane analysis of "Gondwanan Europe". Schriften des Staatlichen Museums für Mineralogie und Geologie zu Dresden 9.

Fiala, F. 1968. Ordovician diabase pillow lavas of the Barrandian area. Věstník Ústředního ústavu geologického 43, 169-182.

Fiala, F. 1978. Proterozoic and Early Paleozoic volcanismof the Barrandian-Železné hory zone. Sborník geologických věd, Geologie, 31, 71-90.

FINK, J.H. 1983. Structure and emplacement of a rhyolitic obsidian flow: Little Glass Mountain, Medicine Lake Highland, northern California. Bulletin of the Geological Society of America 94, 362-380.

DOI 10.1130/0016-7606(1983)94<362:SAEOAR>2.0.CO;2

Fisher, R.V. \& SCHMINCKe, H.U. 1984. Pyroclastic rocks. 472 pp. Springer Verlag, Berlin, Heidelberg, New York \& Tokyo. DOI 10.1007/978-3-642-74864-6

Goldring, R. \& Bridge, P. 1973. Sublitoral sheet sandstones. Journal of Sedimentary Petrology 43, 736-747.

Greenwood, B. \& Sherman, D.J. 1986. Hummocky cross-stratification in the surf zone: Flow parameters and bedding genesis. Sedimentology 33, 33-45.

DOI 10.1111/j.1365-3091.1986.tb00743.x

Harms, J.C., Southard, J.B., Spearing, D.R. \& Walker, R.G. 1975. Depositional environment as interpreted from primary sedimentary structures and stratification sequence. Society of Economic Paleontologists and Mineralogy, Short Course 2, 161.

Harms, J.C., Southard, J.B. \& Walker, R.G. 1982. Structure and sequence in clastic rocks. Society of Economic Paleontologists and Mineralogy, Short Course 9, 249.

HAVLíčEK, V. 1981. Development of a linear sedimentary depresion exemplified by the Prague Basin (Ordovician-Middle Devonian; Barrandian area - Central Bohemia). Sborník geologických věd, Geologie 35, 7-48.

HAVlíčEK, V. 1982a. Lingulacea, Paterinacea, and Siphonotretacea (Brachiopoda) in the Lower Ordovician sequence of Bohemia. Sborník geologických věd, Paleontologie 25, 9-82.

HavlíčEK, V. 1982b. Ordovician in Bohemia: Development of the Prague Basin and its benthic communities. Sborník geologických věd, Geologie 37, 103-136.

HAVLÍčEK, V. \& ŠNAJDR, M. 1956. Paleogeografie tremadockého moře v Barrandienu. Sborník Ústředního ústavu geologického 22, 237-255. [in Czech].

HAVLÍČEK, V. \& ŠNAJDR, M. 1957. Stratigrafický a tektonický výzkum středočeského ordoviku. Výroční zpráva za rok 1956. MS Geofond, Prague. [in Czech]

HAVlíčEK, V. \& ŠNAJdR, M. 1958. Železné rudy Barrandienu. Výpočet zásob Fe-rud v tektonické kře Bechlova a na Rači. Závěrečná zpráva. MS Geofond, Prague. [in Czech]
HAY, R.L. 1963. Stratigraphy and zeolitic diagenesis of the John Day Formation of Oregon. University of California Publications in Geological Sciences 42, 199-262.

KeTtNeR, R. 1916a. Př́íspěvek k petrografii vrstev krušnohorských $\left(\mathrm{d}_{1} \alpha\right)$, část 1 a 2. Rozpravy České akademie pro vědy, slovesnost a umění, Tř́ida II 24(34), 1-64. [in Czech]

KETTNER, R. 1916b. O kambrických vyvřelinách v Barrandienu a jejich poměru k vrstvám krušnohorským. Rozpravy České akademie pro vědy, slovesnost a umění, Tř́da II 25, 38. [in Czech]

KNIGHT, R.J. 1980. Linear sand bar development and tidal current flow in Cobequid Bay, Bay of Fundy, Nova Scotia, 123-152. In McCann, S.B. (ed.) The Coastline of Canada: Littoral processes and shore morphology. Geological Survey of Canada, Paper 80-10.

Kraft, J. \& Kraft, P. 1999. Graptolite biozones of the Bohemia Lower and Middle Ordovician and their historical development. Journal of the Geological Society 44, 1-2.

Kraft, P., Kraft, J. \& Prokop, R.J. 2001. A possible hydroid from the Lower and Middle Ordovician of Bohemia. Alcheringa 25(1-2), 143-154. DOI 10.1080/03115510108619101

KuKAL, Z. 1963. Složení a vznik ordovických sedimentů vrstev třenických a mílinských. Sborník Ústředního ústavu geologického, Oddíl geologický 28, 265-307. [in Czech]

LeCKIE, D.A. \& WaLKeR, R.G. 1982. Storm- and tide-dominated shore-lines in Cretaceous Moosebar - Lower Gates interval outcrop equivalents of deep basin gas trap in western Canada. American Association of Petroleum Geologists Bulletin 66, 138-157.

LOFGREN, G.E. 1971. Spherulitic textures in glassy and crystalline rocks. Journal of Geophysical Research 76, 5635-5648. DOI 10.1029/JB076i023p05635

LowE, D.R. 1982. Sediment gravity flows: II. Depositional models with special reference to the deposits of high-density turbidity currents. Journal of Sedimentary Petrology 52, 279-297.

Manda, Š. 2008. Trocholites Conrad, 1838 (Nautiloidea, Tarphycerida) in the Middle Ordovician of the Prague Basin and its palaeobiogeographical significance. Bulletin of Geosciences 83, 327-334. DOI 10.3140/bull.geosci.2008.03.327

McCave, I.N. \& LANGHORNE, D.N. 1982. Sand waves and sediment transport around the end of tidal sand bank. Sedimentology 29, 95-110.

DOI 10.1111/j.1365-3091.1982.tb01712.x

McPhie, J., Doyle, M. \& Allen, R. 1993. Volcanic textures A guide to the interpretation of textures in volcanic rocks. 196 pp. Centre for Ore Deposit and Exploration Studies, University of Tasmania.

Melichar, R. 2004. Tectonics of the Prague Synform: a hundred years of scientific discussion. Krystalinikum 30, 167-187.

Mergl, M. 1984. Marcusodictyon, an encrusting bryozoan from the Lower Ordovician (Tremadocian) of Bohemia. Věstník Českého geologického ústavu 59(3), 171-172.

Mergl, M. 2002. Linguliformean and craniiformean brachiopods of the Ordovician (Třenice to Dobrotivá Formations) of the Barrandian Bohemia. Acta Musei nationalis Pragae, Series $B$ - historia naturalis 58(1-2), 1-82. 
Mergl, M. 2009. Sukcese fosilních asociací třenického souvrství (tremadoc, ordovik) u Holoubkova (pražská pánev). Zprávy o geologických výzkumech v roce 2008, 101-103. [in Czech]

Mulder, T. \& Syvitski, J.P.M. 1995. Turbidity currents generated at river mouths during exceptional discharges to the world oceans. The Journal of Geology 103, 285-299. DOI 10.1086/629747

Mulder, T., Syvitski, J.P.M., Migeon, S., Faugères, J.C. \& Savoye, B. 2003. Marine hyperpycnal flows: Initiation, behavior and related deposits. A review. Marine and Petroleum Geology 20, 861-882.

DOI 10.1016/j.marpetgeo.2003.01.003

Mutti, E., Tinterri, R., Benevelli, G., Angella, S., di Biase, D. \& Cavanna, G. 2003. Deltaic, mixed and turbidite sedimentation of ancient foreland basins. Marine and Petroleum Geology 20, 733-755. DOI 10.1016/j.marpetgeo.2003.09.001

Paulick, H., Vanko, D.A. \& Yeats, C.J. 2004. Drill core-based facies reconstruction of a deep-marine felsic volcano hosting an active hydrothermal system (Pual Ridge, Papau New Guinea, ODP Leg 193). Journal of Volcanology and Geothermal Research 130, 31-50. DOI 10.1016/S0377-0273(03)00275-0

Plink-BJöRKLund, P. \& SteEl, R. 2004. Initiation of turbidity currents: Evidence for hyperpycnal flow turbidites in Eocene Central Basin of Spitsbergen. Sedimentary Geology 165, 29-52. DOI 10.1016/j.sedgeo.2003.10.013

DE RAAF, J.F.M. \& Boersma, J.R. 1971. Tidal deposits and their sedimentary structures. Geologie Mijnbouw 50, 479-503.

Sandst§, N.R., Robins, B., Furnes, H. \& DE Wit, M. 2011. The origin of large varioles in flow-banded pillow lava from the Hooggenoeg Complex, Barberton Greenstone Belt, South Africa. Contributions to Mineralogy and Petrology. DOI 10.1007/s00410-010-0601-4

Smith, R.K., Tremallo, R.L. \& Lofgren, G.E. 2001. Growth of megaspherulites in a rhyolitic vitrophyre. American Mineralogist 86, 589-600.

SpARKS, R.S.J. 1986. The dimensions and dynamics of volcanic eruption columns. Bulletin of Volcanology 48, 3-15. DOI 10.1007/BF01073509

Stevenson, R.J., Briggs, R.M. \& Hodder, A.P.W. 1994. Physical volcanology and emplacement history of the Ben Lomond rhyolite lava flow, Taupo Volcanic Centre, New Zealand. New Zealand Journal of Geology and Geophysics 37, 345-358. DOI 10.1080/00288306.1994.9514625
Stow, D.A.V. 1986. Deep clastic seas, 99-444. In Reading, H.G. (ed.) Sedimentary environments and facies. Blackwell, Oxford.

SwIFT, D.J.P. 1968. Coastal erosion and transgressive stratigraphy. Journal of Geology 76, 444-456. DOI 10.1086/627342

SwiFT, D.J.P. \& Thorne, J.A. 1991. Sedimentation on continental margin, I: a general model for shelf sedimentation, 3-31. In Swift, D.P.J., Oertel, G.F., Tillman, R.W. \& Thorne, J.A. (eds) Shelf sand and sandstone bodies: Geometry, facies and sequence stratigraphy. Special Publication of the International Asociation of Sedimentologists 14.

TRINCARDI, F. \& FIELD, M.E. 1991. Geometry, lateral variability, and preservation of downlapped regressive shelf deposits: eastern Tyrrhenian margin, Italy. Journal of Sedimentary Petrology 61, 75- 90.

Trofimovs, J., Sparks, R.S.J. \& Talling, P.J. 2008. Anatomy of submarine pyroclastic flow and asociated turbidity current: July 2003 dome collapse, Soufriere Hills volcano, Montserrat, West Indies. Sedimentology 55, 617-634. DOI 10.1111/j.1365-3091.2007.00914.x

TuCKER, M.E. 2001. Sedimentary petrology. An introduction to the origin of sedimentary rocks. $3^{\text {rd }}$ edition. $262 \mathrm{pp}$. WileyBlackwell.

Vidal, P., Auvray, B., Charlott, R., Fediuk, F., Hameurt, J. \& WaLdHAUSROVÁ, J. 1975. Radiometric age of volcanics of the Cambrian "Křivoklát-Rokycany" Complex (Bohemian Massif). Geologische Rundschau 64(2), 563-570. DOI 10.1007/BF01820683

WALKER, R.G. 1992. Facies, facies models and modern stratigraphic concepts, 1-14. In WALKER, R.G. \& JAMES, N.P. (eds) Facies models - response to sea level change. Geological Association of Canada Publications.

Watkins, J., Manga, M., Huber, C. \& Martin, M. 2009. Diffusion-controlled spherulite growth in obsidian inferred from $\mathrm{H}_{2} \mathrm{O}$ concentration profiles. Contribution to Mineralogy and Petrology 157, 163-172. DOI 10.1007/s00410-008-0327-8

YANG, W. 2007. Transgressive wave ravinement on an epicontinental shelf as recorded by an Upper Pennsylvanian soil-nodule conglomerate-sandstone unit, Kansas and Oklahoma, U.S.A. Sedimentary Geology 197, 189-205. DOI 10.1016/j.sedgeo.2006.10.002

Yokoyama, T., Oкumura, S. \& NaKashima, S. 2008. Hydration of rhyolitic glass during weathering as characterized by IR microspectroscopy. Geochimica et Cosmochimica Acta 72, 117-125. DOI 10.1016/j.gca.2007.10.018 